\title{
STUDENT SATISFACTION, LOYALTY, AND MOTIVATION AS OBSERVED FROM THE SERVICE QUALITY
}

\author{
Subandi \\ Administrative Management Academy Yogyakarta, Indonesia \\ subandi@amayogyakarta.ac.id \\ Muda Setia Hamid \\ STIE Widya Wiwaha Yogyakarta, Indonesia \\ mudasetia@stieww.ac.id
}

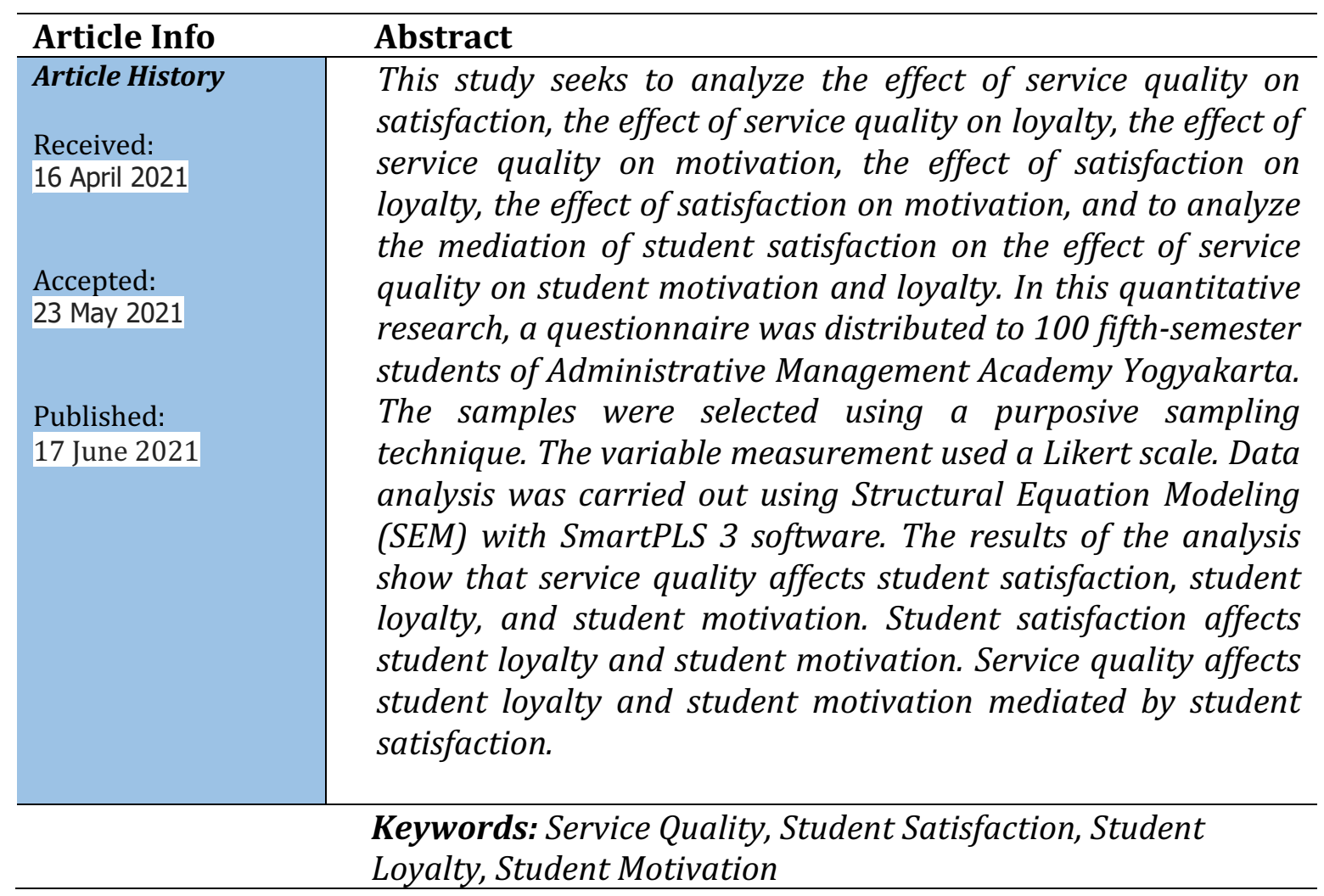

\section{INTRODUCTION}

Higher education is educational institutions in the form of academies, colleges, institutes, and universities. The increasingly intense competition among universities and the demand for quality, accurate, quality, and competitive human resources who are useful in society encourages universities to improve the quality of their services. Trust for quality depends on the satisfaction that universities can provide to their customers.

Higher education is required to produce quality graduates (Yusoft, McLeay, \& Ros, 2013). They are also encouraged to retain their customers, realizing that sustainability depends on the service quality they provide to students as their main customers (Arif, Ilyas, \& Hameed, 2013). The 
globalization era encourages tighter competition in higher education to attract students. Competition among higher education institutions leads them to adopt a market-oriented strategy that can differentiate themselves from their competitors in order to attract as many students as possible (Gisle, 2015). Increased competition among universities to attract new students has a greater emphasis on meeting student expectations and needs (Thomas, 2011).

Competition in higher education in terms of the service providers is very dynamic and challenging (Yusoft et al., 2013). Apart from offering various advantages, universities must also be able to compete in providing the best quality for their users. Concepts such as service quality, student satisfaction, and student loyalty are taken into account in the strategy for the continuity of the institution (Dennis, Papagiannidis, Alamanos, \& Bourlakis, 2016). Service quality is the main performance measure in education and the main strategy for higher-educational institutions as service providers. The service quality from a higher educational institution can provide satisfaction to students (Bhakti \& Sumaedi, 2013). Several empirical studies state that service quality is the cause of customer satisfaction (Jiewanto, Laurens, \& Nelloh, 2012). Research conducted by Annamdevula \& Bellamkonda, (2016) shows that service quality is a variable that affects satisfaction. Other studies that show a significant effect of service quality on satisfaction were carried out by Yamani et al., 2017; Teeroovengadum et al., (2019).

According to Annamdevula \& Bellamkonda, (2016), the next thing related to service quality and student satisfaction is student loyalty. Research on service quality and satisfaction has a significant effect on loyalty. Apart from student loyalty, things related to service quality and student satisfaction are motivation. In the learning process, student motivation is very important that when educational institutions provide better services, students will be motivated in the teaching and learning process which in turn will improve the quality of educational outcomes (Yamani et al., 2017).

Continuous learning is a cognitive involvement for a long time. Thus, student motivation is very crucial. This is a process that educates organizations to provide better services to students; they are motivated to participate in the educational process, which in turn improves the quality of educational outcomes (Stukalina, 2014). Research that shows a significant effect of service quality and satisfaction on motivation is revealed in the study conducted by Annamdevula \& Bellamkonda, (2016).

The number of student admissions for the Administrative Management Academy Yogyakarta in the last five years has fluctuated. However, the number of students in the last five years has not been followed by success in retaining students since, every year, some students leave or do not continue their studies. The annual decline in the number of students ranges from $3 \%$ to 
$5 \%$ of the total number of students. The level of student satisfaction for academic services was declining. The same happened for other services. Some are steady but some have declined also. It is a concern that the level of student satisfaction cannot be fulfilled. Based on this, this study aims to determine whether student satisfaction, loyalty, and motivation are related to or affected by the service qualities provided by the institution.

This study is based on researches conducted by Annamdevula \& Bellamkonda, (2016) and Yamani et al., (2017) but with differences in samples, data analysis techniques, and development of research instruments. The model in this study was tested by using Partial Least Squares (PLS) SEM.

\section{LITERATURE REVIEW}

\section{Service quality}

Service quality is the focus of evaluation that reflects customer perceptions about the specific dimensions of the services provided to fulfill consumer needs and desires and the accuracy of their delivery in balancing consumer expectations (Zeithaml, Bitner, \& Gremler, 2018).

Justin et al (2019) stated that the characteristics of services in higher educational institutions have several types of services of the nature of services, relationships with students, demand and supply, and methods of providing information services. According to Parasuraman (1988), there are five dimensions in service quality called SERVQUAL which consist of tangible, empathy, reliability, responsiveness, and assurance (Lupiyoadi \& Hamdani, 2013). Christian, (1990) explains that the service quality perceived by customers is divided into two main dimensions. They are technical quality (outcome dimension) and functional quality (process-related dimension) (Fandy Tjiptono., 2016).

In higher education, there are several dimensions in measuring service quality. Abdullah, (2006) developed a measurement for service quality called HEdPERF (Higher Education Performance) specifically designed for higher education use. HEdPERF consists of six factors. They are non-academic, academic, reputation, access, program issue, and understanding. Teeroovengadum (2019) suggests a functional and transformative aspect called HESQUAL (higher education service quality) to transforming students through the teaching and learning process (Leibowitz \& Bazalek, 2015).

Senthilkumar \& Arulraj, (2011) offer a model for measuring service quality in higher education called SQM-HEI (Service Quality Measurement in Higher Education in India) consisting of three dimensions, namely teaching methodology, environmental change in study factor, disciplinary action, and outcomes as the result of quality education. Annamdevula \& 
Bellamkonda, (2016) developed a measurement of the quality of higher education services called HiEduQual (Higher Education Quality) consisting of six of quality of teachers or lecturers, administrative services, academic facilities, campus infrastructure, support services, and international cooperation networks.

\section{Student Satisfaction}

Students are consumers of higher education institutions (Guilbault, 2016). Consumer satisfaction is when expectations exceed what is received (Husein Umar, 2013; Kotler, 2016). The concept of consumer satisfaction in education is the evaluation of student subjective experiences of the educational services received when the perceived performance meets or exceeds student expectations shaped by repeated experiences in campus life (Elliott, K. \& Shin, 2002; Stoltenberg, 2011). Higher educational institutions that provide encouragement and high expectations for students to be realized will be successful in academic terms (Popi Setiatin, 2010). Literature shows that there are many aspects affecting student satisfaction such as personal factors, teacher quality, assessment, and learning experience (Stokes, Suzanne, 2003;ADeBourghRN, 2003; Fieger, 2012). Brown \& Mazzarol, (2009) state that student satisfaction can be divided into cognitive satisfaction and affective satisfaction.

Six indicators can function as predictors of student satisfaction in an educational environment. They are quality of lessons, subject matter, collaborative learning, laboratory facilities, institutional support, and library services (Stukalina, 2014). Annamdevula \& Bellamkonda, (2016) in their study formulated student satisfaction consisting of student satisfaction with academic services, student satisfaction with administrative services, student satisfaction with support services, student satisfaction with facilities and facilities, student satisfaction with university or campus management, student satisfaction for all services that have been provided by the university or campus.

\section{Student Loyalty}

Consumer loyalty is an important concept within the competition in maintaining loyal customers to remain loyal (Aritonang \& Lerbin, 2014). According to Singh \& Sirdeshmukh, (2014), customer loyalty is customer behavior in maintaining relationships with institutions through the purchase of products and services.

Loyalty is one of the important elements for the success of a company (Setó-Pamies, 2012). Loyal customers are willing to pay more, and repurchase, engage in positive word-of-mouth and thus bring many benefits to the company. These benefits include a larger market share, reduced operating costs, and increased profits (Woods, 2014). 
Eskildsen, J., Martensen, A., Lars, G., \& Kai, (2000) in their study suggested the dimensions of loyalty consisting of customers' desire for the next purchase, willingness to recommend an institution or brand to others, tolerance of price changes, and the desire of customers to buy other products from the institution (cross-sell). Khadka \& Maharjan (2017) divide customer loyalty into three different categories that include behavior loyalty, intentional loyalty, and emotional loyalty. In the field of education, student loyalty refers to student loyalty in educational institutions, willingness to provide good information by word of mouth, feeling proud to be part of the university, being involved in advancing the university, recommending it to friends and family, having a desire to complete the study (Thomas, 2015; Jaroslav et al., 2012; Kunanusorn \& Puttawong, 2015; Annamdevula \& Bellamkonda, 2016).

\section{Motivation}

Motivation can be interpreted as a person's strength, direction, and persistence to achieve goals (Robbins, SP ., 2015; Damaris et al., 2019). In education, motivation is the energy and encouragement of students to study, work hard, and excel in school which fosters activities and provides orientation for learning activities (Martin, 2001; Winkel et al., 2011).

Student motivation is very important for a long time cognitive engagement and a continuous educational process (Annamdevula \& Bellamkonda, 2016). This process makes educational institutions try to provide better services to students; they are motivated to participate in the educational process, which in turn improves the quality of educational outcomes (Stukalina, 2014). Educational services play a central role in students live that requires great motivation and intellectual skills to achieve their goals (Gruber T Fuß, Voss, \& Gläser-Zikuda, 2010).

Learning motivation after the lecture process can be seen through changes in student behavior, students with high motivation will learn more and will be more successful than those who have less motivation (Mustamin, Ahmad, Jasruddin, Syam, \& Fitriani, 2019).

There are two motivational factors, intrinsic motivation internal motivation, such as the desire to learn and gain knowledge, and extrinsic motivation that comes from external factors (Ryan \& Deci, 2000). Factors that influence student motivation based on service quality in higher educational institutions include teaching methods and methods of lecturers, academic services, administrative support and services, university facilities, and university environment (Annamdevula \& Bellamkonda, 2016; Siswoyo et al., 2012; Kousar et al., 2015; Naibaho et al., 2012; Suwastika, 2017).

\section{Conceptual Framework}

The quality of a product, either goods or services, can contribute to customer satisfaction (Fandy Tjiptono., 2016). Customer satisfaction can be seen as an assessment of the services 
provided based on the experience obtained during service provision. Service quality is an essential prerequisite for building and maintaining satisfying relationships with valued customers. The relationship between service quality and customer satisfaction has emerged as an important and strategic topic.

In the context of higher education, several studies have examined and proven the relationship between service quality and student satisfaction (Annamdevula \& Bellamkonda, 2016; Chandra et al., 2018; Yamani et al., 2017; Teeroovengadum et al., 2019; Justin et al., 2019; Ismanova, 2019). In educational services, loyalty is needed to develop solid relationships with students that will provide the basis for future university activities; academic institutional services significantly affect student achievement and loyalty (Annamdevula \& Bellamkonda, 2016; Yamani et al., 2017; Justin et al., 2019; Kousar et al., 2015).

Motivation is a person's strength that can generate enthusiasm for doing something. This power can come from within or from outside the individual. Several studies have shown that service quality affects student motivation. (Annamdevula \& Bellamkonda, 2016; Yamani et al., 2017; Justin et al., 2019; Kousar et al., 2015).

A person's satisfaction with a service can increase loyalty, the higher the satisfaction, the higher the loyalty. Student loyalty in the higher education sector helps higher education managers to build appropriate programs in terms of promotion and maintain long relationships with students and alumni. The results showed that student satisfaction affects loyalty (Annamdevula \& Bellamkonda, 2016; Kousar et al., 2015; Arif et al., 2013).

Higher educational institutions should take into account students' needs and appropriate motivation in supporting the teaching and learning process. Lack of services provided will lead to student dissatisfaction, which ultimately results in sub-optimal academic achievement. Research shows that student satisfaction affects student motivation (Annamdevula \& Bellamkonda, 2016; Stukalina, 2014).

Customers who are truly loyal not only have the potential to become word-of-mouth advertisers but are also more likely to be loyal to the company's product and service portfolio over the years. In educational services, loyalty is needed to develop solid relationships with students and provide the basis for future university activities. Research shows that student satisfaction mediates the relationship between student perceptions of service quality and student loyalty (Annamdevula \& Bellamkonda, 2016; Kousar et al., 2015; Arif et al., 2013; Justin et al., 2019). 


\section{METHOD}

\section{Population and Sample}

This descriptive quantitative research employs explanatory research. According to Sugiyono (2015), explanatory research aims to reveal the position of the variables under study and the relationship between variables using another variable. The population in this study is the fifthsemester students of the Administrative Management Academy Yogyakarta. The number of samples used for the PLS-SEM analysis according to Ghozali \& Latan (2015) is between 30-100 or ten times the endogenous variables. Hair et al., (2011) recommend that if the number of latent variables is $\leq 5$ with the number of indicators $>3$, the number of samples needed is 100-150. This study used 4 latent variables with the number of indicators for each variable $>3$. Thus, in this study, the sample used was 100 respondents. Samples were taken using non-probability sampling with the purposive sampling technique.

\section{Data Collection and Data Analysis}

The data in this study were collected using a survey through questionnaires. The questionnaire in this study was distributed online via Google Forms. The technique of calculating the data from the questionnaire results used a Likert scale where the alternative answers are scaled from 1 to 5, namely strongly disagree, disagree, quite agree, agree, and strongly agree.

The data analysis used Partial Least Square (PLS), which is variance-based SEM employing Smart PLS 3.0 software which includes testing the outer model/measurement model and testing the inner model/structural model. The outer model or measurement model is to test the relationship between indicators and construct variables. The indicator test obtained the output of the validity and reliability of the model as measured by the criteria of convergent validity, discriminant validity, and reliability.

The inner model or structural model is a hypothesis test that tests the relationship and effect between latent variables using the bootstrap with a significance value used (two-tailed) tvalue of 1.65 for a significant level of $10 \%$ and a t-value of 1.96 for a $5 \%$ significance level (Hair et al., 2011). Testing the mediation was carried out using the Sobel test by testing the strength of the exogenous indirect effect on endogenous variables through the mediating variable (Ghozali, 2016). Zhao et al., (2010) divided the mediation effect into partial mediation when a and $\mathrm{b}$ are significant, c is significant, full mediation when a and b are significant, but c is not significant., direct-only (no mediation) when a and b are not significant, but $\mathrm{c}$ is significant and No effect (no mediation) if $\mathrm{a}$ and $\mathrm{b}$ are not significant and $\mathrm{c}$ is not significant. To evaluate the structural model by looking at the value of R-Squares, $\mathrm{Q}^{2}$ predictive relevance, effect Size $/ \mathrm{f}^{2}$, and Goodness of Fit $(\mathrm{GoF})$. 


\section{RESULTS}

\section{Respondent's Characteristics}

Table 1 presents the characteristics of 100 students in this study.

Table 1. Respondent's Characteristics

\begin{tabular}{|c|l|c|c|}
\hline Characteristics & \multicolumn{1}{|c|}{ Category } & Frequency & $\mathbf{\%}$ \\
\hline \multirow{2}{*}{ Gender } & Female & 77 & $77 \%$ \\
& Male & 23 & $23 \%$ \\
\hline \multirow{5}{*}{ Age } & 19 Years Old & 12 & $12 \%$ \\
& 20 Years Old & 34 & $34 \%$ \\
& 21 Years Old & 37 & $37 \%$ \\
& 22 Years Old & 14 & $14 \%$ \\
& 23 Years Old & 2 & $2 \%$ \\
& 24 Years Old & 1 & $1 \%$ \\
\hline
\end{tabular}

Table 1 shows that this study consisted of 77 female students and 23 male students. Most were between the ages of 20 and 22 years old.

\section{Outer Model}

Based on the PLS output in Figure 2, evaluation can be carried out to determine the convergent validity of each of the observed indicator values. The results of the convergent validity show that all loading factor values are greater than 0.70 . Thus, all indicators are declared valid.

Figure 2. Loading Factor, path coefficient, and R Squares

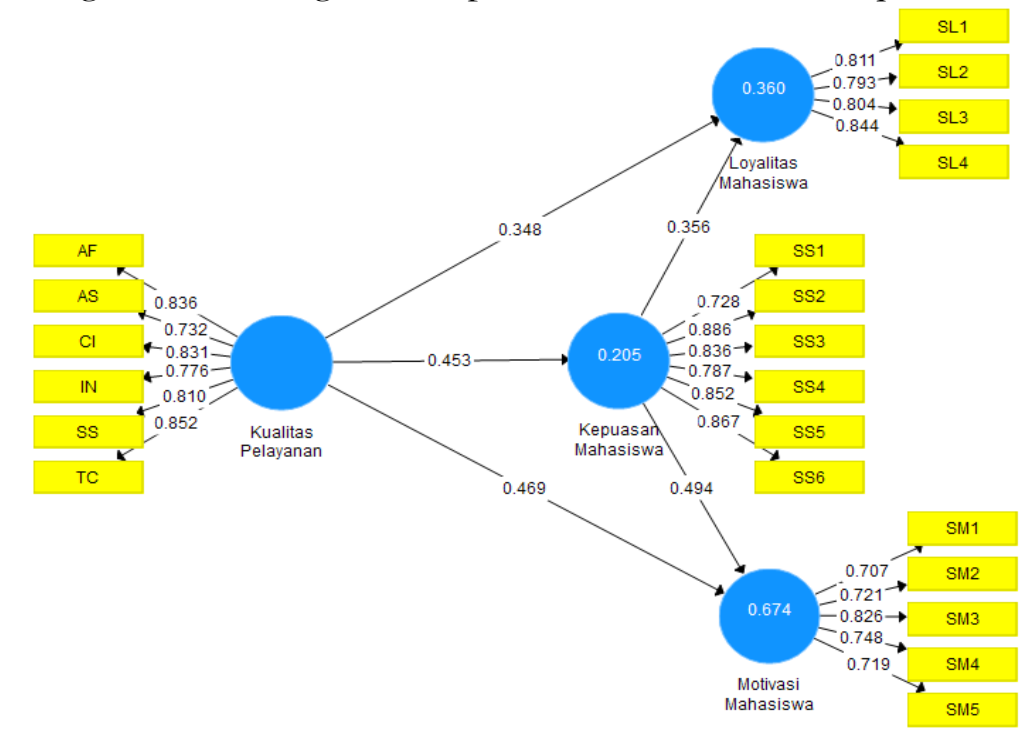

The PLS results on the AVE value in Table 2 show that the indicators in the model are all valid, where all AVE values are greater than 0.5. To ensure that there are no problems related to the measurement of the structural model, the step taken is to test the unidimensional models using indicators of composite reliability and alpha Cronbach. A construct can be said to be reliable if the value of Composite Reliability and Cronbachs Alpha of $>0.70$. Table 2 shows that all indicators 
144 Subandi \& Hamid, M. S., Student Satisfaction, Loyalty, and Motivation as Observed From...

have Composite Reliability and Cronbachs Alpha values above 0.7. Thus, it can be concluded that the research model is reliable in measuring constructs.

Table 2. Value of AVE, Composite Reliability and Cronbachs Alpha

\begin{tabular}{|l|l|c|c|}
\hline \multicolumn{1}{|c|}{ Construct } & AVE & Composite Reliability & Cronbachs Alpha \\
\hline Service Quality & 0.652 & 0.918 & 0.892 \\
Student Satisfaction & 0.685 & 0.929 & 0.908 \\
Student Loyalty & 0.661 & 0.886 & 0.830 \\
Student Motivation & 0.556 & 0.862 & 0.801 \\
\hline
\end{tabular}

To find out the discriminant validity, it can be seen from the Fornell-Larcke and Heterotrait-Monotrait Ratio (HTMT) values that can be seen in Table 3. Table 3 shows that the square root of the AVE value is greater than the respective correlation between constructs and the HTMT of all variables is $<0.90$. Hence, it fulfills discriminant validity.

Table 3. Value of Fornell-Larcke and Heterotrait-Monotrait Ratio (HTMT)*

\begin{tabular}{|c|c|c|c|c|c|}
\hline Construct & $\begin{array}{l}\text { Service } \\
\text { Quality }\end{array}$ & $\begin{array}{c}\text { Student } \\
\text { Satisfaction }\end{array}$ & $\begin{array}{l}\text { Student } \\
\text { Loyalty }\end{array}$ & $\begin{array}{c}\text { Student } \\
\text { Motivation }\end{array}$ & $\begin{array}{c}\text { AVE Square } \\
\text { Root }\end{array}$ \\
\hline $\begin{array}{l}\text { Service } \\
\text { Quality }\end{array}$ & - & & & & 0.807 \\
\hline $\begin{array}{l}\text { Student } \\
\text { Satisfaction }\end{array}$ & $\begin{array}{c}0.453 \\
(0.489)^{*}\end{array}$ & - & & & 0.828 \\
\hline $\begin{array}{l}\text { Student } \\
\text { Loyalty }\end{array}$ & $\begin{array}{c}0.509 \\
(0.551)^{*}\end{array}$ & $\begin{array}{c}0.514 \\
(0.590)^{*}\end{array}$ & - & & 0.813 \\
\hline $\begin{array}{l}\text { Student } \\
\text { Motivation }\end{array}$ & $\begin{array}{c}0.693 \\
(0.773)^{*}\end{array}$ & $\begin{array}{c}0.707 \\
(0.781)^{*}\end{array}$ & $\begin{array}{c}0.714 \\
(0.891)^{*}\end{array}$ & - & 0.745 \\
\hline
\end{tabular}

\section{Inner Model}

The structural model or inner model is carried out to see the effect of the relationship among the variables. The t-statistic and the Sobel test were carried to see the mediating effect. The t-test output with PLS Boostrap can be seen in Figure 3.

Figure 3. The Results of the t-test with Boostrap

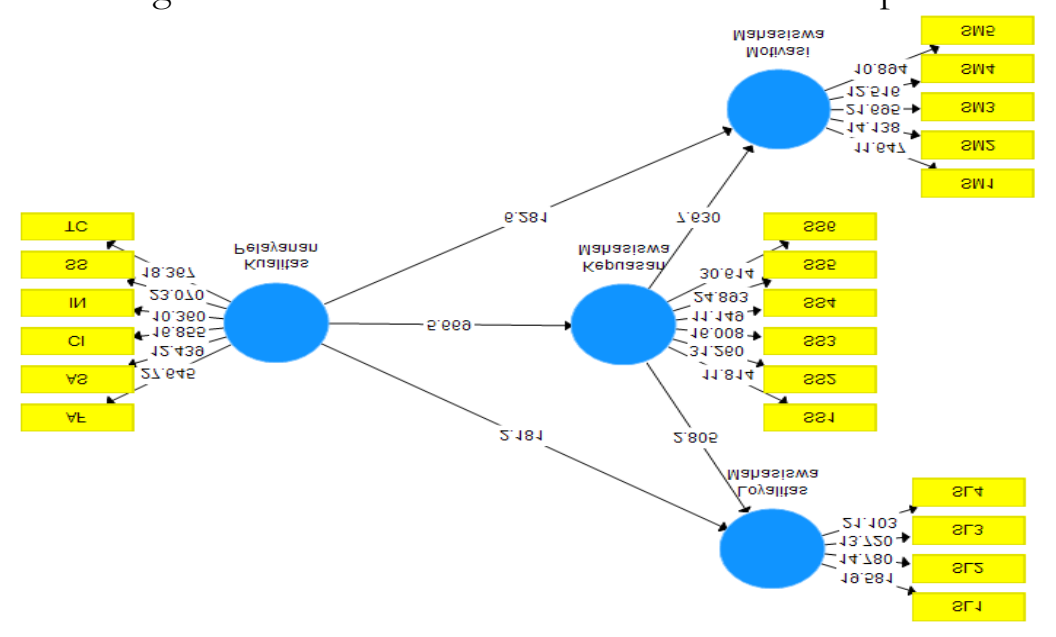


Based on the results of hypothesis testing, it was found that the seven hypotheses were accepted because they had a t-value $>1.96$ and a $\mathrm{p}$-value $<0.05$. The results of the analysis related to hypothesis testing can be seen in Figure 3 and Table 4.

Table 4. Direct, Indirect and Total Effects * in the Structural Model

\begin{tabular}{|c|c|c|c|c|c|}
\hline No. & Effect & \begin{tabular}{c|} 
Path \\
Coefficient
\end{tabular} & $\begin{array}{c}T \\
\text { value }\end{array}$ & $\begin{array}{c}\mathbf{P} \\
\text { value }\end{array}$ & Results \\
\hline 1 & $\begin{array}{l}\text { Service Quality -> Student } \\
\text { Satisfaction }\end{array}$ & 0.453 & 5.669 & 0.000 & Significant \\
\hline 2 & Service Quality -> Student Loyalty & 0.348 & 2.181 & 0.030 & Significant \\
\hline 3 & $\begin{array}{l}\text { Service Quality -> Student } \\
\text { Motivation }\end{array}$ & 0.469 & 6.281 & 0.000 & Significant \\
\hline 4 & Service Quality -> Student Loyalty & 0.356 & 2.805 & 0.005 & Significant \\
\hline 5 & $\begin{array}{l}\text { Student Satisfaction -> Student } \\
\text { Motivation }\end{array}$ & 0.494 & 7.630 & 0.000 & Significant \\
\hline 6 & $\begin{array}{l}\text { Service Quality -> Student } \\
\text { Satisfaction -> Student Loyalty }\end{array}$ & $\begin{array}{c}0.161 \\
(0.509)^{*}\end{array}$ & 2.514 & 0.011 & Significant \\
\hline 7 & $\begin{array}{l}\text { Service Quality -> Student } \\
\text { Satisfaction -> Student Motivation }\end{array}$ & $\begin{array}{c}0.224 \\
(0.693)^{*}\end{array}$ & 4.550 & 0.000 & Significant \\
\hline
\end{tabular}

The evaluation of the inner model was done by looking at $\mathrm{R}^{2}, \mathrm{Q}^{2}$, and GoF. The results of the model assessment can be seen in table 5 . The R Square value of student satisfaction is 0.205 , this shows the relationship between service quality and student satisfaction is weak. The Rsquare value for the student loyalty construct is 0.360 , this shows a moderate relationship between service quality and student satisfaction with student loyalty. The R-square value for the construct of student motivation is 0.674 . This indicates that the relationship between service quality and student satisfaction with student motivation is strong. $Q^{2}$ value for all constructs was $>0$. Thus, the model has predictive relevance. The GoF (Goodness of Fit) value is 0.513 . Thus, the overall model has a big GoF (Goodness of Fit).

Table 5. Goodness of Fit

\begin{tabular}{|l|c|c|c|}
\hline \multicolumn{1}{|c|}{ Construct } & $\mathbf{R}^{2}$ & $\mathbf{Q}^{2}$ & Gof \\
\hline Student Satisfaction & 0,205 & 0,131 & \\
Student Loyalty & 0,360 & 0,215 & 0,513 \\
Student Motivation & 0,674 & 0,331 & \\
\hline
\end{tabular}

\section{DISCUSSION}

\section{The Effect of Service Quality on Student Satisfaction}

The results showed that the service quality had affect student satisfaction. It can be concluded that the hypothesis stating that service quality has an effect on student satisfaction is 
accepted. Customer satisfaction can be seen as an assessment of the services provided based on the experience gained during service provision. Service quality is an essential prerequisite for building and maintaining satisfying relationships with valued customers. In this way, the relationship between service quality and customer satisfaction has emerged as an important and strategic topic. Students are the main consumers in higher education, therefore the service quality provided can give satisfaction to students. The results of this study support previous research from Annamdevula \& Bellamkonda, (2016) regarding the effect of perceived service quality on satisfaction, loyalty, and motivation of students in India revealing the effect of service quality on student satisfaction. These results are also in line with research of Yamani et al., (2017) that if the service qualitys provided increases, students will feel satisfied. The results of this study also support research conducted by Bakrie et al., (2019) on the effect of service quality, institutional reputation, student satisfaction, and loyalty.

\section{The Effect of Service Quality on Student Loyalty}

Service quality has a positive and significant effect on student loyalty. Based on these results, it can be concluded that the hypothesis stating that service quality has an effect on student loyalty is accepted. Student loyalty refers to student loyalty in educational institutions. Loyalty has short-term and long-term impacts on educational institutions. Student loyalty is a combination of the willingness to provide good word of mouth about the institution and recommendations about it to family and friends. The basis for future university activities requires student loyalty as a result of educational services. The results of this study support previous research from Annamdevula \& Bellamkonda, (2016) that service quality affects student loyalty in India and research by Yamani et al., (2017) that service quality affects student loyalty at the Poltekkes Kemenkes Banjarmasin.

\section{The Effect of Service Quality on Student Motivation}

Service quality has a positive and significant effect on student motivation. In this study, it can be concluded that the hypothesis stating that service quality has an effect on student motivation is accepted. In education, motivation is the energy and encouragement of students to study, work hard, and excel in school (Martin, 2001). Student motivation is very important for a long cognitive engagement and a continuous educational process (Annamdevula \& Bellamkonda, 2016). This process makes educational institutions try to provide better services to students, they are motivated to participate in the educational process, which in turn improves the quality of educational outcomes (Stukalina, 2014).

Higher educational institutions that provide good services cause students to be motivated in the educational process, and in turn, improve the quality of educational outcomes. Student motivation is very important in a sustainable education process (Yamani et al., 2017). The results 
of this study support previous research from Annamdevula \& Bellamkonda, (2016) that service quality affects student motivation in India and research by Yamani et al., (2017) that the service quality affects the motivation of students of the Poltekkes Kemenkes Banjarmasin. The results of this study are in line with Justin et al., (2019) regarding the attitudes of international students in China regarding the effect of service quality on motivation, satisfaction, loyalty, and institutional image.

\section{The Effect of Student Satisfaction on Student Loyalty}

Student satisfaction has a positive and significant effect on student loyalty. Based on these result of this study, it can be concluded that the hypothesis that student satisfaction affects student loyalty is accepted. Satisfaction can increase loyalty. The higher the satisfaction, the higher the loyalty. Student loyalty will help universities in building promotional programs as well as developing and maintaining relationships between students and alumni (Annamdevula \& Bellamkonda, 2016). The results of this study support previous research from Annamdevula \& Bellamkonda, (2016) that student satisfaction affects student loyalty in India and a research conducted by Justin et al., (2019) that satisfaction affects international student loyalty in China. However, this result is contrary to the research of Yamani et al., (2017) that concluded that satisfaction does not affect student loyalty. This shows that student satisfaction cannot make students stay and continue lectures until completion.

\section{The Effect of Student Satisfaction on Student Motivation}

The results of this study show that student satisfaction has a positive and significant effect on student motivation. Based on these results, it can be concluded that the hypothesis stating student satisfaction affects student motivation is accepted. Higher educational institutions must see the needs and appropriate motivation of students in supporting the teaching and learning process. Poor service quality will make students dissatisfied so that it has an impact on sub-optimal academic achievement. The results of this study support previous research from Annamdevula \& Bellamkonda, (2016) that student satisfaction affects student motivation in India and research conducted by Justin et al., (2019) that satisfaction affects the motivation of international students in China. However, this result is contrary to the research of Yamani et al., (2017) that satisfaction does not affect student motivation. This shows that student satisfaction has not been able to motivate students to learn.

\section{The Effect of Service Quality on Student Loyalty mediated by Student Satisfaction}

The results of this study show that student satisfaction mediates the relationship between service quality and student loyalty. The very tight competition among universities encourages universities and colleges to continue to improve the quality of their services in order to meet 
market demands (Chandra et al., 2018). Good service quality increases student satisfaction and leads to student loyalty because the level of service quality determines the number of students enrolled at the university (Chen, 2015). Student loyalty is needed to develop future university activities (Annamdevula \& Bellamkonda, 2016).

The results of this study support previous research from Annamdevula \& Bellamkonda, (2016) that student satisfaction mediates the effect of service quality on student loyalty in India, as well as research conducted by Justin et al., (2019) that satisfaction is a mediating variable between service quality and international student loyalty in China. But this result is contrary to the research of Yamani et al., (2017) that satisfaction does not mediate the relationship between service quality and loyalty, which means that the service provided to students can foster student loyalty even though it is not without satisfaction.

\section{The Effect of Service Quality on Student Motivation mediated by Student Satisfaction}

The results of this study show that student satisfaction mediates the relationship between service quality and student motivation. Student motivation is very important in a sustainable educational process. When educational organizations provide quality service to students, students will be motivated to participate in the educational process, and in turn, improve the quality of educational outcomes (Annamdevula \& Bellamkonda, 2016).

Service quality has a positive effect on satisfaction which is a potential consequence of student motivation. Poor service from the academic staff, administrators, and other support staff causes students to feel isolated, which in turn results in poor academic motivation (Mason, 2012). Quality service can have a direct impact on student mood and participation, which in turn builds motivation (Stukalina, 2014).

The results of this study support previous research from Annamdevula \& Bellamkonda, (2016) that student satisfaction mediating the effect of service quality on student motivation in India, as well as research carried out by Justin et al., (2019) that satisfaction is a mediating variable between service quality and motivation of international students in China. However, this result is contrary to the research of Yamani et al., (2017) that satisfaction does not mediate the relationship between service quality and motivation, which means that services provided to students can motivate students even without satisfaction.

\section{CONCLUSION}

All seven hypotheses were accepted. Service quality has a direct positive and significant effect on satisfaction, loyalty, and motivation. Student satisfaction has a direct positive and significant effect on student loyalty and motivation at the Administrative Management Academy 
Yogyakarta. Student satisfaction mediates the relationship between service quality and loyalty and motivation of students at the Administrative Management Academy Yogyakarta. The more satisfied students with the service quality, the more loyalty and motivation will be. The best strategy in this study is to improve the service quality to increase student satisfaction since it has the greatest value in increasing student motivation. The results of hypothesis testing can be developed into information for the management of the Administrative Management Academy Yogyakarta in providing services to create student satisfaction, increase student motivation, and strengthen student loyalty.

There are several limitations in this study including the research sample which is only for students of the Administrative Management Academy Yogyakarta. Thus, this study has limitations in generalizing to universities or organizations other than service sectors. Respondents in this study were students aged 19-24 years, which means that if the same research is conducted on magister/ doctoral students of different ages, it may yield different results.

\section{REFERENCES}

Abdullah, F. (2006). The development of HEdPERF: A new measuring instrument of service quality for the higher education sector. International Journal of Consumer Studies, 30(6), 569-581. https://doi.org/10.1111/j.1470-6431.2005.00480.x

ADeBourghRN, G. (2003). Predictors of student satisfaction in distance-delivered graduate nursing courses: what matters most. Journal of Professional Nursing, 19(3), 149-163.

Annamdevula, S., \& Bellamkonda, R. S. (2016). Effect of student perceived service quality on student satisfaction, loyalty and motivation in Indian universities: Development of HiEduQual. Journal of Modelling in Management, 11(2), 488-517. https://doi.org/10.1108/JM2-01-2014-0010

Arif, S., Ilyas, M., \& Hameed, A. (2013). Student satisfaction and impact of leadership in private universities. TQM Journal, 25(4), 399-416. https://doi.org/10.1108/17542731311314881

Aritonang, \& Lerbin. (2014). Student loyalty modeling. Trziste, 26(1), 77-91.

Bakrie, M., Sujanto, B., \& Rugaiyah. (2019). The Influence of Service Quality , Institutional Reputation, Students' S atisfaction on Students 'Loyalty in Higher Education. 1(5), 379-391.

Bhakti, G., \& Sumaedi. (2013). An analysis of library customer loyalty: The role of service quality and customer satisfaction, a case study in Indonesia. Library Management, 34(6), 397-414.

Brown, R. M., \& Mazzarol, T. W. (2009). The importance of institutional image to student satisfaction and loyalty within higher education. Higher Education, 58(1), 81-95. https://doi.org/10.1007/s10734-008-9183-8

Chandra, T., Ng, M., Chandra, S., \& Priyono. (2018). The effect of service quality on student satisfaction and student loyalty: An empirical study. Journal of Social Studies Education Research, 
9(3), 109-131. https://doi.org/10.17499/jsser.12590

Chen, Y.-C. (2015). An Empirical Study on the Student Experience of Higher Education Service Quality in Taiwan. International Journal of Management Sciences, 6(12), 582-594.

Christian, G. (1990). Service Management and Marketing: Managing the Moment of Truth in Service Competition (Issues in Organization and Management Series). Lexington Books.

Damaris, A., Surip, N., \& Setyadi, A. (2019). Analysis service on student satisfaction with motivation as moderating variable. International Journal of Economics and Business Administration, 7(2), 118-130. https://doi.org/10.35808/ijeba/220

Dennis, C., Papagiannidis, S., Alamanos, E., \& Bourlakis, M. (2016). The role of brand attachment strength in higher education. 69, 3049-3057.

Elliott, K. \& Shin, D. (2002). Student satisfaction: an alternative approach to assessing this Important ConceptNo Title. Journal of Higher Education Policy and Management, 24(2), 97-109.

Eskildsen, J., Martensen, A., Lars, G., \& Kai, K. (2000). Benchmarking student satisfaction in higher education based on the ECSI methodology. Sinergie Italian Journal of Management, 9(18), $385-402$.

Fandy Tjiptono. (2016). Service, Quality \& satisfaction. Yogyakarta: Andi Ofset.

Fieger, P. (2012). Measuring student satisfaction from the Student Outcomes Survey. National Centre for Vocational Education Research, 1-17.

Ghozali, I. (2016). Model Persamaan Sruktural Konsep dan Aplikasi dengan Program AMOS 24 Update Bayesian SEM. (7th ed.). Semarang: Badan Penerbit Universitas Diponegoro.

Ghozali, I., \& Latan, H. (2015). Partial Least Squares Konsep, Teknik dan Aplikasi Mengunakan Program SmartPLS 3.0 Untuk Penelitian Empiris. (2nd ed.). Semarang: Badan Penerbit Universitas Diponegoro.

Gisle, H. T. E. (2015). The importance of university facilities for student satisfaction at a Norwegian University. Facilities, 33(13/14), 744-759.

Gruber T Fuß, S., Voss, R., \& Gläser-Zikuda, M. (2010). Examining Student Satisfaction with Higher Education Services: Using A New Measurement Tool Examining Student Satisfaction with Higher Education Services Using a New Measurement Tool The University of Manchester University of Education Ludwigsburg HWZ Un. (May 2014). https://doi.org/10.1108/09513551011022474

Guilbault. (2016). Students as customers in higher education: reframing the debate. Journal of Marketing for Higher Education, 26(2), 132-142. https://doi.org/10.1080/08841241.2016.1245234

Hair, J. F., Ringle, C. M., \& Sarstedt, M. (2011). PLS-SEM: Indeed a silver bullet. Journal of Marketing Theory and Practice, 19(2), 139-152. https://doi.org/10.2753/MTP1069-6679190202

Husein Umar. (2013). Riset Pemasaran dan Perilaku Konsumen. Jakarta: Gramedia Pustaka Utama.

Ismanova, D. (2019). Students' loyalty in higher education: The mediating effect of satisfaction, trust, commitment on student loyalty to Alma Mater. Management Science Letters, 9(8), 1161- 
1168. https://doi.org/10.5267/j.msl.2019.4.024

Jaroslav, D., Taborecka, P., Cuzovicband, S., \& Rajicc, T. (2012). An empirical examination of the relationships between service quality, satisfaction and behavioral intentions in higher education settin. Serbian Journal of Management, 7(2), 203-218. https://doi.org/10.5937/sjm.v7i2.1245

Jiewanto, A., Laurens, C., \& Nelloh, L. (2012). Influence of Service Quality, University Image, and Student Satisfaction toward WOM Intention: A Case Study on Universitas Pelita Harapan Surabaya. Procedia - Social and Behavioral Sciences, 40(December 2012), 16-23. https://doi.org/10.1016/j.sbspro.2012.03.155

Justin, D., Lekini Jin, S., \& Hubert, V. (2019). Effect of International Students' Perceived Service Quality on the Student's Motivation, Satisfaction, Loyalty, and Institutional Image in Higher Education in China. International Journal of Science and Business, 3(2), 110-125. https://doi.org/10.5281/zenodo.2587994

Khadka, K., \& Maharjan, S. (2017). Customer Satisfaction And Customer Loyalty (Case Trivsel Städtjänster). Centria University Of Applied Sciences Business Management.

Kotler, P. (2016). Marketing Management, 15th. New Jersey: Pearson Pretice Hall, Inc.

Kousar, S., Ilyas, M., \& Abdul, C. (2015). Mediating Model Of Hypothesized Effect OfAcademic \& Institutional Services On Student Achievement \&Loyalty. Sci.Lnt(Labore), 27(2), 13871394.

Kunanusorn, A., \& Puttawong, D. (2015). the Mediating Effect of Satisfaction on Student Loyalty To Higher Education Institution. European Scientific Journal, 1(October), 1857-7881.

Leibowitz, \& Bazalek. (2015). Foundation provision - a social justice perspective: part 1. South African Journal of Higher Education, 29(1), 8-25.

Lupiyoadi, \& Hamdani, A. (2013). Manajemen Pemasaran Jasa Berbasis Kompetensi (3rd ed.). Jakarta: Salemba Empat.

Martin, A. J. (2001). Student Motivation Scale. Journal of Guidance and Counselling, 11, 1-20.

Mason, M. M. (2012). Motivation, satisfaction, and innate psychological needs. International Journal of Doctoral Studies, 7, 259-277. https://doi.org/10.28945/1596

Mustamin, Ahmad, A., Jasruddin, Syam, A., \& Fitriani. (2019). The effect of academic services quality toward the cadets learning motivation at Politeknik Ilmu Pelayaran Makassar. International Journal of Learning, Teaching and Educational Research, 18(10), 128-141. https://doi.org/10.26803/ijlter.18.10.8

Naibaho, H., Adi, F., . V., \& . S. (2012). Pengaruh Lingkungan Kampus Terhadap Motivasi Belajar Mahasiswa (Studi Kasus Universitas Pelita Harapan Surabaya. Jurnal Manajemen Pemasaran, 5(1), 22-26. https://doi.org/10.9744/pemasaran.5.1.22-26

Popi Setiatin. (2010). Manajemen Belajar Berbasis Kepuasan Siswa. Bogor: Ghalia Indonesia.

Robbins, SP ., \& J. T. A. (2015). Perilaku Organisasi (16th ed.). Jakarta: Salemba Empat. 
Ryan, R. M., \& Deci, E. L. (2000). Self-Determination Theory and the Facilitation of Intrinsic Motivation, Social Development, and Well-Being. 55(1), 68-78.

Senthilkumar, \& Arulraj. (2011). SQM-HEI - determination of service quality measurement of higher education in India. Journal of Modelling in Management, 6(1), 60-78. https://doi.org/10.1108/17465661111112502

Setó-Pamies, D. (2012). Customer loyalty to service providers: Examining the role of service quality, customer satisfaction and trust. Total Quality Management and Business Excellence, 23(1112), 1-15.

Singh, \& Sirdeshmukh. (2014). Agency and Trust Mechanisms in Consumer Satisfaction and Loyalty Judgments. (August). https://doi.org/10.1177/0092070300281014

Siswoyo, H., Suyitno, S., \& Marlikan, M. (2012). Kontribusi Kinerja Mengajar Dosen Dan Media Pembelajaran Terhadap Motivasi Belajar Mahasiswa. Erudio Journal of Educational Innovation, 1(1). https://doi.org/10.18551/erudio.1-1.6

Stokes, Suzanne, P. (2003). Temperament, Learning Styles, and Demographic Predictors of CollegeStudent Satisfaction in a Digital Learning Environment. 1-36.

Stoltenberg. (2011). Investigating the concept of student satisfaction: The case of international students at the UiO. 1-67.

Stukalina, Y. (2014). Identifying Predictors of Student Satisfaction and Student Motivation in the Framework of Assuring Quality in the Delivery of Higher Education Services. Business, Management and Education, 12(1), 127-137. https://doi.org/10.3846/bme.2014.09

Sugiyono. (2015). Metode Penelitian Bisnis. Bandung: Alfabeta.

Suwastika, I. W. K. (2017). Pengaruh Lingkungan Terhadap Motivasi Belajar Mahasiswa Stikom Bali. Jurnal Ilmiah Manajemen \& Akintansi, 23(2), 75-88. https://doi.org/2301-8291

Teeroovengadum, V., Nunkoo, R., Gronroos, C., Kamalanabhan, T. J., \& Seebaluck, A. K. (2019). Higher education service quality, student satisfaction and loyalty: Validating the HESQUAL scale and testing an improved structural model. Quality Assurance in Education, 27(4), 427445. https://doi.org/10.1108/QAE-01-2019-0003

Thomas, S. (2015). What Drives Student Loyalty in Universities: An Empirical Model from India What Drives Student Loyalty in Universities: An Empirical Model from India. (July). https://doi.org/10.5539/ibr.v4n2p183

Winkel, D. E., Wyland, R. L., Shaffer, M. A., \& Clason, P. (2011). A new perspective on psychological resources: Unanticipated consequences of impulsivity and emotional intelligence. Journal of Occupational and Organizational Psychology, 84(1), 78-94. https://doi.org/10.1348/2044-8325.002001

Woods, H. H. \& D. P. (2014). Attitudinal and Behavioral Aspects of Loyalty in the Screen-Golf Industry. Journal of Quality Assurance in Hospitality \& Tourism, 15(2), 175-189.

Yamani, M., Said, L. R., \& Dahniar. (2017). Pengaruh Kualitas Layanan Terhadap Motivasi Dan Loyalitas Mahasiswa Dengan Kepuasan Mahasiswa Sebagai Variabel Mediasi (Studi Pada 
Poltekkes Kemenkes Banjarmasin. Jurnal Wawasan Manajemen, 5(2), 125-144.

Yusoft, M., McLeay, F., \& Ros, H. R. (2013). Dimensions driving business student satisfaction in higher education. Quality Assurance in Education, 23(1), 86-104.

Zeithaml, V., Bitner, M. J., \& Gremler, D. (2018). Service. Marketing:Integrating Customer Focus Across the Firm. Boston: Mc.Graw-Hill.

Zhao, X., Lynch, J. G., \& Chen, Q. (2010). Reconsidering Baron and Kenny: Myths and truths about mediation analysis. Journal of Consumer Research, 37(2), 197-206. https://doi.org/10.1086/651257 